\title{
Chemical and physical characterization of mume fruit collected from different locations and at different maturity stages in São Paulo State
} Ernesto QUAST $^{1 *}$, Isabelli VIEIRA², Alessandro NOGUEIRA², Flavio Luis SCHMIDT ${ }^{3}$

\begin{abstract}
Prunus mume is widely studied due to its health benefits regarding increase of blood fluidity and consequent improvement of the cardiovascular system and the prevention or even the fight against different types of cancer. However, in Brazil this culture is found only among oriental descendants. The present study aimed to characterize mume fruit collected from three different locations in the State of São Paulo regarding general aspects such as pH, total titratable acidity (TTA), total soluble solids (TTS), pectin content and yield of pulp and chemical characteristics: total phenolic compounds (TPC) and antioxidant capacity. Mume fruit were collected unripe and analyzed until maturation about 88 days after flowering. Fruit collected in Botucatu came from a commercial mume fruit producer and had average weight of $16.9 \mathrm{~g}$, while in fruit from other locations weight varied from 5.7-6.9 g. TSS ranged from 9.5 to 10.0 Brix, total solids was $10.2-12.2 \%$ and $\mathrm{pH}$ showed values between 2.5 and 2.7 for all

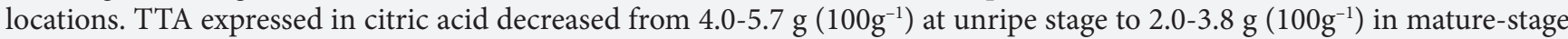
fruit. Pectin content decreased from 11.2 to $10.8 \%$ during fruit maturation, TPC content was $147-226 \mathrm{mg}^{-3 t e c h i n}\left(\mathrm{~g}^{-1}\right)$ on a dry matter basis and the antioxidant capacity was $96-169 \mu \mathrm{Mol}$ Trolox $\left(\mathrm{g}^{-1}\right)$ on a dry matter basis or $21-34 \mu \mathrm{Mol}$ Trolox $\left(\mathrm{g}^{-1}\right)$ on a wet matter basis.
\end{abstract}

Keywords: mume; fruit characterization; health product.

\section{Introduction}

The family Rosaceae is one of the largest Angiosperm family. Regarding the economic aspect, it is one of the most important families, including apple (Malus sylvestris), pear (Pyrus communis), peach (Prunus persica), plum (Prunus salicina), strawberry (Fragaria vesca), yellow plum (Eriobotrya japonica), cranberry (Rubus idaeus) and mume (Prunus mume). Plants from this family are cultivated in South and Southeast regions of Brazil because of the milder weather conditions, favorable to the development of temperate fruit (SOUZA; LORENZI, 2005). Mume tree exhibits an arboreal growth and 4-6 meters high, with white and androgynous flowers that bloom from June to August. Fruit are drupaceous, with firm pulp with bitter and sour taste and maturity from October to December (LORENZI et al., 2006).

Asia, in particular China, is the birth place of mume culture, where production, consumption and acceptance are high. Further, in Asia there are different cultivars that include early and late fruit producing plants, so the harvest interval increases to three or four months. For the same plant, the interval for harvesting does not exceed three weeks.

In the State of São Paulo, mume trees were introduced in 1960's by Asian descendants and even though in Brazil there are no studies to improve yield and quality of fruit, there are over 200 cultivars of Prunus mume Siebold et Zucc. worldwide, whose fruit are consumed mainly in Korea, China and Japan (TSUBAKI; OZAKI; AZUMA, 2010). In Japan fruit price is about 1.68 US dollar $\left(\mathrm{kg}^{-1}\right)$, and present an average yield of 6.7 ton $\left(\mathrm{ha}^{-1}\right.$ ) (JUN; CHUNG, 2008; TOPP; NOLLER; RUSSEL, 2007).

P. mume has been studied in Brazil as rootstocks for peach (Prunus persica) and plums (Prunus salicina), showing promising characteristics, such as rusticity, high resistance to pests and diseases (MAYER; PEREIRA; MÔRO, 2008). These characteristics suggest that mume fruit can be produced in large scale without or with less use of pesticides.

Mume fruit can be collected directly from the tree, shaken to fall in large clothes, nets or trimmed grass at unripe-stage or dropped by their own while still green but physiologically mature. At this stage, maturation occurs at temperature above $20{ }^{\circ} \mathrm{C}$ ventilated (LUO, 2006) because mume fruit display a typical climacteric pattern of respiration and ethylene biosynthesis. The removal of over-ripe and injured fruit reduces significantly the presence of insects and flies during harvest and maturation. Texture, color and aroma of these fruits change significantly during maturation (MIYAZAWA et al., 2009).

Several mume processed products have been consumed as healthy foods and for the treatment of several diseases because they are rich in bioactive compounds, such as anti-cancer and antioxidant substances (TSUBAKI; OZAKI; AZUMA, 2010; LIU et al., 2009; SHI et al., 2009; ADACHI et al., 2007; SHI; MOY, 2005). Given the similarity of unripe apricot and mume

\footnotetext{
Received 1/11/2012

Accepted 22/5/2013 (005930)

${ }^{1}$ Federal University of the Southern Border-UFFS, Rod. BR 158, Km 07, CP 106, CEP 85301-970, Laranjeiras do Sul, PR, Brazil,

e-mail:ernesto.quast@uffs.edu.br,equast00@gmail.com

2 State University of Ponta Grossa - UEPG, Ponta Grossa, PR, Brazil

3 State University of Campinas - UNICAMP, Campinas, SP, Brazil

${ }^{*}$ Corresponding author
} 
fruit, Jun and Chung (2008) developed sequence-characterized amplified region (SCAR) markers to differentiate mume fruit due to its higher value and demand. This identification can be used both for germplasm classification and to detect apricot unripe fruit commercialized as mume fruit. Jo et al. (2006) used mume fruit extract as a natural source of antioxidant compounds, which can inhibit lipid oxidation and formation of "warmed over flavor" volatiles during storage of cooked chicken meat. Mume extract inhibits free radical formation during initial stages of oxidation. At high concentrations, these highly reactive free radicals break triglyceride chains to produce free carboxylic acid that provide product alteration.

The present study aimed to characterize mume fruit collected from three different locations in the State of São Paulo regarding general aspects such as $\mathrm{pH}$, total titratable acidity (TTA), total soluble solids (TTS), pectin content and yield of pulp and chemical characteristics: total phenolic compounds (TPC) and antioxidant capacity. These results can help to decide the best option: breeding or adaptation of new cultivars, for the introduction of mume to locations where currently peach and plums are grown in Brazil. Also, fruit characterization is needed to permit its use as ingredient for food production.

\section{Materials and methods}

\subsection{Plant material}

Fruit used were green-to-yellow color soon after natural fruit dropping occurred, approximately $88 \mathrm{DAF}$ (days after flowering) and were stored for up to 8 days at $26^{\circ} \mathrm{C}$ ventilated until complete ripening. In previous studies, fruit were collected from the trees weekly from $60 \mathrm{DAF}$ and fruit did not mature properly.

Mume fruit were collected in São Paulo State, Brazil, from different locations:

- S - Angatuba, SP- Latitude $23^{\circ} 30^{\prime} 43^{\prime \prime} \mathrm{S}$; Longitude $48^{\circ}$ 16' 38" W; Elevation 737 m;

- CB - Capão Bonito, SP- Lat. 2402’ 52” S; Long. 48²1’ 19" W; Elev. 705 m;

- SUN - Botucatu, SP- Lat. 22 57' 56” S; Long. 48 27’ 25” W; Elev. 843 m.

According to Koppen climate classification, all locations are Cwa, characterized as highland tropical climate, with rainfall in summer and dry winter, with average temperature of the warmest month above $22{ }^{\circ} \mathrm{C}$. In Angatuba, mume trees were planted as windbreak for peach and plum culture and in Capão Bonito, trees were planted for ornamental purpose. Botucatu was the only commercial mume production found in the State of São Paulo, with plants brought from China in the 1960's. SUN was the only location where the pruning of the tree was done. Pesticides were not applied to any fruit and plants used in the present work.

Physical analysis were performed in 40 fruit from each location using a caliper (Marberg) accurate to $0.05 \mathrm{~mm}$ and digital scale (Mettler Toledo, AB204) accurate to $0.1 \mathrm{mg}$. Pulp yield was determined for each fruit manually by separating into three different fractions: skin, flesh and kernel with use of latex gloves and knife. Each fraction was weighed separately soon after separation.

\subsection{Chemical analysis}

Full-mature fruit were used for total soluble solids (TSS) and total titratable acidity (TTA) content analysis. Analyses were performed in duplicate for each sample using 4 different samples for each location. For each sample, 8 fruit were manually pulped. TSS results were obtained using a digital refractometer Reichert, AR200, expressed in Brix. TTA was expressed in percentage of citric acid, analyzed in duplicate for each sample, using 4 different samples for each treatment or location. Total solids content were analyzed with four repetitions of $10 \mathrm{~g}$ of fruit from each location and dried in circulation heater at $105^{\circ} \mathrm{C}$ for 24 hours (INSTITUTO..., 2008).

Pectin content was examined by mixing $4 \mathrm{~g}$ of lyophilized mume with $1: 50$ nitric acid $50 \mathrm{mM}$ at $80^{\circ} \mathrm{C}$ for 25 minutes. After filtration and cooling to $4^{\circ} \mathrm{C}$, the acid extract was mixed with $1: 2$ ethanol $96^{\circ} \mathrm{GL}$ at $4{ }^{\circ} \mathrm{C}$ and allowed to stand still for 30 minutes. After this period, was filtered and kept inside permeable bags overnight with ethanol $70 \%$ under agitation. Then, washed again with ethanol $95 \%$, and dried at $40{ }^{\circ} \mathrm{C}$. Pectin analysis was performed in triplicate.

\subsection{Sample preparation for phenol and antioxidant analysis}

For total phenol content and antioxidant power analysis, an extraction solution was previously prepared by mixing ethanol 70\%: distilled water: formic acid 3\% (80:20:1) as described by McGhie, Hunt and Barnett (2005) with modifications. Samples containing 8 fruit were frozen at $-86{ }^{\circ} \mathrm{C}$ for at least 2 days before being lyophilized (Terroni, LD1500A). Next, 2.5 grams of dried pulp with peel were weighed in a centrifuge tube and mixed with $25 \mathrm{~mL}$ of the extraction solution. The product was placed in contact with the extraction solution at $15{ }^{\circ} \mathrm{C}$ for 24 hours and then immediately centrifuged (Celm, Combate) for 10 minutes at 2,232 $\mathrm{g}(3,500 \mathrm{rpm})$. Previous studies were performed to adjust the composition of the extraction solution, ratio of the dried product to the amount of extraction solution and extraction time to ensure the extraction of most of the phenolic compounds and reproducibility of the results. Samples were identified and maintained in closed flasks inside a freezer for up to 4 months for analysis of total phenol content and antioxidant activity.

For each location, fruit samples were prepared from 1 day after harvest (DAH) until complete maturation, up to $8 \mathrm{DAH}$.

\subsection{Ferric-reducing antioxidant power (FRAP) assay}

The reducing ability was determined by using the FRAP assay (BENZIE; STRAIN, 1996). The FRAP reagent was freshly prepared from $300 \mathrm{mmol}\left(\mathrm{L}^{-1}\right)$ acetate buffer ( $\left.\mathrm{pH} 3.63\right), 10 \mathrm{mmol}$ $\left(\mathrm{L}^{-1}\right)$ tripyridyltriazine (TPTZ) made up in $40 \mathrm{mmol}\left(\mathrm{L}^{-1}\right) \mathrm{HCl}$

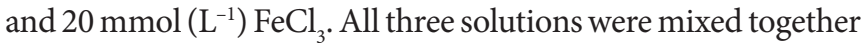
in the ratio of $10: 1: 1(\mathrm{v} / \mathrm{v} / \mathrm{v})$. An aliquot of $0.1 \mathrm{~mL}$ of the tested 
sample solution was mixed with $3.0 \mathrm{~mL}$ of FRAP reagent. The absorption of the reaction mixture was measured at $593 \mathrm{~nm}$ after 15 minutes incubation at $26^{\circ} \mathrm{C}$. The reducing capacity was expressed as trolox equivalent (TE) concentration.

FRAP analyses were performed in duplicate.

\subsection{Determination of total phenolic content}

Total phenolic content of ethanol extracts was determined with the Folin-Ciocalteu colorimetric method (SINGLETON; ROSSI JUNIOR, 1965) with some modifications. Briefly, $0.1 \mathrm{ml}$ extract was diluted with $8.4 \mathrm{ml}$ distilled water and mixed with $0.5 \mathrm{ml}$ Folin-Ciocalteu reagent by manual shaking for 1520 seconds. After 3 minutes, $1.0 \mathrm{ml}$ of $20 \%$ sodium carbonate solution was added. The reaction mixture was incubated at room temperature for 1 hour and absorbance was measured at $720 \mathrm{~nm}$ using a dual beam UV-Vis spectrophotometer (Shimadzu, Mod. UV-Mini 1240). Catechin (SIGMA, C-1251) was used as an analytical standard for total phenolic quantification and it was expressed in milligrams of catechin equivalents (CE) per gram of dried fruit.

TPC analyses were performed in triplicate.

\subsection{Statistical analysis}

Analysis were performed in random sequence of experiments and significant differences in treatment means were checked using STATISTICA software (version 5.5, StatSoft Inc., Tulsa, OK, USA) using Tukey's test ( $\mathrm{p}<0.05)$.

\section{Results and discussion}

\subsection{Plant material}

Fruit from $C B$ and $S$ were not significantly different $(p<0.05)$ in size and weight; $\mathrm{CB}$ fruit presented diameter, height and mass of $2.239 \pm 0.125 \mathrm{~cm}, 2.310 \pm 0.125 \mathrm{~cm}$ and $6.892 \pm 1.058 \mathrm{~g}$, and $\mathrm{S}$ fruit, $2.130 \pm 0.174 \mathrm{~cm}, 2.304 \pm 0.199 \mathrm{~cm}$ and $5.701 \pm 1.298$, respectively. Fruit from SUN location were significantly larger in size and heavier in weight, with diameter $3.153 \pm 0.264 \mathrm{~cm}$, height $3.164 \pm 0.215 \mathrm{~cm}$ and mass $16.909 \pm 3.667 \mathrm{~g}$.

The location SUN is the only commercial mume fruit producer and although fruit were larger and heavier compared to other locations, SUN fruit were still at the lower limit of weight as reported by Jun and Chung (2008) probably due to genetic improvement in Asian countries. Mume plants studied are well-adapted to local climate and soil and the introduction of new crops from Asia can provide larger fruits or adaptation difficulties.

Even though $\mathrm{S}$ and $\mathrm{CB}$ locations showed smaller kernel compared to SUN location, relative pulp yield was not different between locations. Fruit flesh represented $71.3 \% \pm 2.7$ of total weight of fresh fruit while skin and stone represented $13.8 \% \pm 1.7$ and $14.9 \% \pm 2.0$ respectively. This relative yield of pulp is lower than reported by Tsubaki, Ozaki and Azuma (2010) that obtained $82.7 \% \pm 2.9$ of flesh. This difference is probably due to the smaller size of the fruit in the present work and genetic improvement in Asian countries.

For all locations, TSS was not significantly different during maturation of fruit and ranged from 9.5 to $10.0^{\circ} \mathrm{Brix}$. Total solids content ranged from 10.2 to $12.2 \%$. The $\mathrm{pH}$ value varied little and showed values between 2.5 and 2.7 due to the high acid content with TTA values of $4.0-5.7 \mathrm{~g}\left(100 \mathrm{~g}^{-1}\right)$ at green-stage fruit and 2.0-3.8 $\mathrm{g}\left(100 \mathrm{~g}^{-1}\right)$ at mature-stage fruit, expressed in citric acid. These values are similar to those found in lemons and limes (PENNISTON et al., 2008).

In general, fruit do not present high acceptance when ratio values (SST:TTA) are below 5 . TSS did not vary significantly but TTA decreased during maturation. In consequence, ratio of fruit increased during maturation, but even fully-ripe mume fruit presented ratio values below 5 , making product unacceptable by most consumers of fresh fruit. Thus, the consumption of mume fruit is recommended as processed-food products, where the ratio can be increased by sugar incorporation or acid dilution. These products show a healthy appeal, due to the high antioxidant capacity of the fruit (QUAST et al., 2011).

Pectin content decreased slightly during maturation, from $11.2 \pm 0.1 \%$ to $10.8 \pm 0.1 \%$ expressed on a dry matter basis. This provides approximately $1.32 \%$ on a wet matter basis that represents about half of pectin content in citric fruit and is similar to apple pomace (BAKER, 1997).

\subsection{Ferric-reducing antioxidant power (FRAP) assay}

Fruit collected from the CB location showed in general higher FRAP values during maturation. FRAP values did not vary significantly during maturation of fruit in the $\mathrm{CB}$ location. Another tendency was observed in fruit from the $S$ and especially from the SUN location, where antioxidant capacity tend to lower during maturation of mume fruit. Antioxidant capacity from the CB location ranged from 145 to $170 \mu \mathrm{Mol}$ TE per gram of dry fruit. In S and SUN locations, these results ranged from 96 to $160 \mu \mathrm{Mol} \mathrm{TE} \mathrm{g}{ }^{-1} \mathrm{DF}$. Previous studies performed in samples "hot-filled" and kept inside a glass container sealed for one year at room temperature resulted in an antioxidant capacity of about 70-80 $\mu \mathrm{Mol} \mathrm{TE} \mathrm{g}^{-1} \mathrm{DF}$. This indicates that the compounds responsible for the antioxidant capacity of mume products can be kept sealed for one year without need of refrigeration and maintain about $50 \%$ of its original antioxidant capacity.

The antioxidant capacity ranged from $21-35 \mu \mathrm{Mol} \mathrm{TE} \mathrm{g}^{-1}$ of fresh fruit for all locations. These values are shown in Table 1 and are comparable to that of guavas and blueberries, 18-32 and $13-46 \mu \mathrm{Mol} \mathrm{TE} \mathrm{g}{ }^{-1}$ of fresh fruit, respectively (THAIPONG et al., 2006).

\subsection{Determination of total phenolic content (TPC)}

According to Table 2, CB fruit presented a trend of higher TPC values compared to other locations. This difference is probably a result of differences among cultivars, since climate is similar for all locations. It can also be observed that TPC did not vary during maturation of fruit, except for SUN location, which 3 DAH showed similar TPC values as fruits collected 
Table 1. FRAP assay of mume fruit collected from different locations and in different days after harvest - DAH.

\begin{tabular}{lcc}
\hline \multicolumn{1}{c}{ Samples } & $\begin{array}{c}\text { Antioxidant capacity } \\
\left(\mu \text { Mol TE g } ~_{-1} \text { DF }\right)^{\star}\end{array}$ & $\begin{array}{c}\text { Antioxidant capacity } \\
\left(\mu \text { Mol TE g } \text { FF }^{-1}\right.\end{array}$ \\
\hline CB - 1 DAH & $145.65 \pm 18.62^{\mathrm{ab}}$ & $27.24 \pm 3.44^{\mathrm{ab}}$ \\
CB - 2 DAH & $154.21 \pm 24.18^{\mathrm{a}}$ & $30.51 \pm 4.07^{\mathrm{ab}}$ \\
CB - 3 DAH & $166.63 \pm 11.09^{\mathrm{a}}$ & $32.94 \pm 2.73^{\mathrm{ab}}$ \\
CB - 4 DAH & $153.01 \pm 9.55^{\mathrm{a}}$ & $31.17 \pm 2.84^{\mathrm{ab}}$ \\
CB - 5 DAH & $169.26 \pm 5.84^{\mathrm{a}}$ & $34.45 \pm 4.85^{\mathrm{a}}$ \\
CB - 8 DAH (ripe fruit) & $162.31 \pm 3.88^{\mathrm{a}}$ & $33.27 \pm 1.51^{\mathrm{ab}}$ \\
S - 3 DAH & $96.48 \pm 22.59^{\mathrm{b}}$ & $21.35 \pm 5.47^{\mathrm{b}}$ \\
S - 4 DAH & $125.48 \pm 9.51^{\mathrm{ab}}$ & $28.74 \pm 2.25^{\mathrm{ab}}$ \\
S - 5 DAH & $131.55 \pm 10.14^{\mathrm{ab}}$ & $30.81 \pm 2.58^{\mathrm{ab}}$ \\
S - 6 DAH & $116.52 \pm 0.86^{\mathrm{b}}$ & $26.91 \pm 0.39^{\mathrm{ab}}$ \\
S - 7 DAH (ripe fruit) & $116.34 \pm 14.81^{\mathrm{b}}$ & $26.96 \pm 4.65^{\mathrm{ab}}$ \\
SUN - 3 DAH & $159.34 \pm 6.95^{\mathrm{a}}$ & $31.42 \pm 1.39^{\mathrm{ab}}$ \\
SUN - 4 DAH & $136.59 \pm 12.33^{\mathrm{ab}}$ & $28.18 \pm 2.36^{\mathrm{ab}}$ \\
SUN - 5 DAH & $119.21 \pm 21.10^{\mathrm{b}}$ & $23.57 \pm 3.95^{\mathrm{b}}$ \\
SUN - 6 DAH & $116.99 \pm 32.34^{\mathrm{ab}}$ & $22.35 \pm 6.43^{\mathrm{ab}}$ \\
SUN - 7 DAH & $117.25 \pm 10.63^{\mathrm{b}}$ & $23.78 \pm 1.88^{\mathrm{ab}}$ \\
(ripe fruit) & & \\
\hline
\end{tabular}

${ }^{*}$ Least significant difference was 25.50 and $5.88 \mu \mathrm{Mol}$ trolox-equivalent $\left(\mathrm{g}^{-1}\right)$ of dry fruit and fresh fruit, respectively. ${ }^{a, b}$ Means with different letters in the same column differ significantly $(\mathrm{p}<0.05)$ in Tukey's test.

Table 2. Total phenolic content of mume pulp+peel collected from different locations and in different days after harvest - DAH.

\begin{tabular}{lcc}
\hline \multicolumn{1}{c}{ Samples } & $\begin{array}{c}\text { Phenolic content } \\
(\text { mg CE g }\end{array}$ & $\begin{array}{c}\text { Phenolic content: } \\
\text { Antioxidant capacity } \\
\text { (mg CE: } \mu \text { Mol TE) }\end{array}$ \\
\hline CB - 1 DAH & $199 \pm 21^{\text {abcd }}$ & 1,366 \\
CB - 2 DAH & $207 \pm 27^{\text {abc }}$ & 1,342 \\
CB - 3 DAH & $228 \pm 16^{\mathrm{a}}$ & 1,368 \\
CB - 4 DAH & $203 \pm 31^{\mathrm{abc}}$ & 1,327 \\
CB - 5 DAH & $226 \pm 2^{\mathrm{a}}$ & 1,335 \\
CB - 8 DAH (ripe fruit) & $215 \pm 15^{\mathrm{ab}}$ & 1,325 \\
S - 3 DAH & $147 \pm 27^{\mathrm{e}}$ & 1,524 \\
S - 4 DAH & $161 \pm 8^{\mathrm{de}}$ & 1,283 \\
S - 5 DAH & $162 \pm 3^{\mathrm{de}}$ & 1,231 \\
S - 6 DAH & $144 \pm 11^{\mathrm{e}}$ & 1,236 \\
S - 7 DAH (ripe fruit) & $160 \pm 31^{\mathrm{de}}$ & 1,375 \\
SUN - 3 DAH & $226 \pm 7^{\mathrm{a}}$ & 1,418 \\
SUN - 4 DAH & $178 \pm 20^{\mathrm{bcde}}$ & 1,303 \\
SUN - 5 DAH & $164 \pm 15^{\text {cde }}$ & 1,376 \\
SUN - 6 DAH & $148 \pm 11^{\mathrm{e}}$ & 1,265 \\
SUN - 7 DAH (ripe fruit) & $169 \pm 7^{\text {cde }}$ & 1,441
\end{tabular}

${ }^{\star}$ Expressed in $\mathrm{mg}$ of catechin-equivalent per gram of dry fruit. Different letters indicate significant difference $(\mathrm{p}<0.05)$. Least significant difference $(\mathrm{LSD})$ was 22 . a,b,c,d,e Means with different letters in the same column differ significantly $(\mathrm{p}<0.05)$ in Tukey's test.

from CB location. During ripening TPC values for SUN location where similar to those of fruits collected at $S$ location. This information is highly relevant because most studies about Prunus mume products are related to health benefits of unripe fruit consumption. Therefore, it is possible to develop different products with ripe mume fruit, keeping health appeal.

Mume fruit collected from the CB location presented significantly higher TPC values but the antioxidant capacity was similar to fruit collected from other locations. This suggests that CB fruit probably present different phenolic composition with lower antioxidant power that can be result of differences in cultivar or soil. In fruit collected from all locations, the increase of antioxidant power was directly proportional to the TPC increase and the ratio TPC:FRAP (mg CE: $\mu \mathrm{Mol} \mathrm{TE}$ ) ranged from 1.23 to 1.52 for mume fruit for all locations, similar to studies in different European plum genotypes (RUPASINGHE; JAYASANKAR; LAY, 2006).

\section{Conclusions}

The present work showed that mume trees grown in São Paulo State give fruits significantly different with average diameter of $2.1-2.3 \mathrm{~cm}$ in $\mathrm{CB}$ and $\mathrm{S}$ location and $3.1-3.2 \mathrm{~cm}$ in SUN location. Mass of fruit ranged from 5.7 to $6.9 \mathrm{~g}$ in CB and S, $16.9 \mathrm{~g}$ in SUN. Yield of fruit flesh and TSS was not significantly different between locations and represented about $71.3 \%$ of total weight and 9.5-10.0 Brix, respectively. TTA decreased during maturation of fruit ranging from 4.0-5.7 to $2.0-3.8 \mathrm{~g}\left(100 \mathrm{~g}^{-1}\right)$ citric acid. Pectin content ranged from 10.8 to $11.2 \%$ on a dry matter basis. The antioxidant capacity evaluated by the FRAP assay ranged from 96 to $170 \mu \mathrm{Mol} \mathrm{TE}\left(\mathrm{g}^{-1}\right)$ dry fruit and it was observed a direct proportionality to the TPC, that ranged from 144 to $228 \mathrm{mg} \mathrm{CE}\left(\mathrm{g}^{-1}\right) \mathrm{DF}$.

\section{References}

ADACHI, M. et al. The Prunus mume Sieb. et Zucc (Ume) is a rich natural source of novel anti-cancer substance. International Journal of Food Properties, v. 10, n. 2, p. 375-384, 2007. http://dx.doi. org/10.1080/10942910600547624

BAKER, R. A. Reassessment of some fruit and vegetable pectin levels. Journal of Food Science, v. 62, n. 2, p. 225-229, 1997. http://dx.doi. org/10.1111/j.1365-2621.1997.tb03973.x

BENZIE, I. F. F.; STRAIN, J. J. The ferric reducing ability of plasma (FRAP) as a measure of "antioxidant power": the FRAP assay. Analytical Biochemistry, n. 239, p. 70-76, 1996.

INSTITUTO ADOLFO LUTZ - IAL. Normas Analíticas do Instituto Adolfo Lutz: Métodos químicos e físicos para análise de alimentos. 4. ed. São Paulo: Secretaria de Estado da Saúde, 2008. 1020 p.

JO, S.-C. et al. Antioxidant activity of Prunus mume extract in cooked chicken breast meat. International Journal of Food Science and Technology, v. 41, n. 1, p. 15-19, 2006. http://dx.doi.org/10.1111/ j.1365-2621.2006.01234.x

JUN, J. H.; CHUNG, K. H. Development of SCAR markers to differentiate between mume (Prunus mume Sieb. et Zucc.) and apricot (P. armeniaca L.). Journal of Horticultural Science \& Biotechnology, v. 83, n. 3, p. 318-322, 2008.

LIU, L. et al. The possible mechanisms of Fructus Mume pill in the treatment of colitis induced by 2,4,6-trinitrobenzene sulfonic acid in rats. Journal of Ethnopharmacology, n. 126, p. 557-564, 2009. PMid:19703546. http://dx.doi.org/10.1016/j.jep.2009.08.013

LORENZI, H. et al. Frutas brasileiras e exóticas cultivadas: (de consumo in natura). São Paulo: Instituto Plantarum, 2006.

LUO, Z. Hot water treatment of postharvest mei fruit to delay ripening. HortScience, v. 41, n. 3, p. 737-740, 2006.

MAYER, N. A.; PEREIRA, F. M.; MÔRO, F. V. Caracterização morfológica de três genótipos de umezeiro selecionados como porta-enxertos para pessegueiro. Revista Brasileira de 
Fruticultura, v. 30, n. 3, p. 716-722, 2008. http://dx.doi.org/10.1590/ S0100-29452008000300026

McGHIE, T. K.; HUNT, M.; BARNETT, L. E. Cultivar and growing region determine the antioxidant polyphenolic concentration and composition of apples grown in New Zealand. Journal of Agricultural and Food Chemistry, v. 53, n. 8, p. 3065-3070, 2005. PMid:15826060. http://dx.doi.org/10.1021/jf047832r

MIYAZAWA, M. et al. Comparision of the volatile componentes of unripe and ripe Japanese apricot (Prunus mume Sieb. et Zucc.). Natural Product Research, v. 23, n. 17, p. 1567-1571, 2009. PMid:19851921. http://dx.doi.org/10.1080/14786410500462926

PENNISTON, K. L. et al. Quantitative assessment of citric acid in lemon juice, lime juice, and commercially-available fruit juice products. Journal of Endourology, v. 22, n. 3, p. 567-570, 2008. PMid:18290732 PMCid:PMC2637791. http://dx.doi.org/10.1089/ end.2007.0304

QUAST, E. et al. Prunus mume - fruit characteristics and phenolic content capacity. Fruit Processing, p. 238-242, Nov/Dec 2011.

RUPASINGHE, H. P. V.; JAYASANKAR, S.; LAY, W. Variation in total phenolics and antioxidant capacity among European plum genotypes. Scientia Horticulturae, v. 108, n. 3, p. 243-246, 2006. http://dx.doi.org/10.1016/j.scienta.2006.01.020

SHI, J.; MOY, J. H. Functional foods from fruit and fruit products. In: SHI, J.; HO, C.-T.; SHAHIDI, F. Asian functional foods.
Boca Raton: CRC Press, 2005. p. 303-339. http://dx.doi. org/10.1201/9781420028119

SHI, J. et al. Antioxidant capacity of extract from edible flowers of Prunus mume in China and its active components. LWT - Food Science and Technology, v. 42, n. 2, p. 477-482, 2009.

SINGLETON, V. L.; ROSSI JUNIOR, J. A. Colorimetry of total phenolics with phosphomolybdic-phosphotungstic acid reagents. American Journal of Enology and Viticulture, v. 16, n. 3, p. 144158, 1965.

SOUZA, V. C.; LORENZI, H. Botanica sistemática: guia ilustrado para identificação das famílias de Angiospermas da flora brasileira, baseado em APG II. São Paulo: Instituto Plantarum, 2005.

THAIPONG, K. et al. Comparison of ABTS, DPPH, FRAP and ORAC assays for estimating antioxidant activity from guava fruit extracts. Journal of Food Composition and Analysis, n. 19, p. 669-675, 2006.

TOPP, B. L.; NOLLER, J.; RUSSELL, D. M. Development of Prunus mume, a new tree crop for Australia. Australia: Rural Industries Research and Development Corporation, 2007. 113 p.

TSUBAKI, S.; OZAKI, Y.; AZUMA, J. Microwave-assisted autohydrolysis of Prunus mume stone for extraction of polysaccharides and phenolic compounds. Journal of Food Science, v. 75, n. 2, p. 152157, 2010. PMid:20492219. http://dx.doi.org/10.1111/j.17503841.2009.01466.x 